\title{
Analysis of polymorphisms in Interleukin 10, NOS2A, and ESR2 genes in chronic and aggressive periodontitis
}

\author{
Virginia Régia Souza SILVEIRA(a) \\ Suzane Cristina PIGOSSI(b) \\ Raquel Mantuaneli \\ SCAREL-CAMINAGA(b) \\ Joni Augusto CIRELLI(c) \\ Rodrigo RÊGO(a) \\ Nádia Accioly Pinto NOGUEIRA(d)
}

(a) Universidade Federal do Ceará - UFC, Campus Sobral, School of Dentistry, Department of Dentistry, Sobral, CE, Brazil.

(b) Universidade Estadual Paulista Júlio de Mesquita Filho - UNESP, School of Dentistry at Araraquara, Department of Morphology, Araraquara, SP, Brazil.

(c) Universidade Estadual Paulista Júlio de Mesquita Filho - UNESP, School of Dentistry at Araraquara, Department of Oral Diagnosis and Surgery, Araraquara, SP, Brazil.

(d) Universidade Federal do Ceará - UFC, Faculty of Pharmacy, Dentistry and Nursing, Department of Clinical and Toxicological Analyses, Fortaleza, CE, Brazil.

Declaration of Interests: The authors certify that they have no commercial or associative interest that represents a conflict of interest in connection with the manuscript.

\section{Corresponding Author:}

Virginia Régia Souza da Silveira

E-mail: virrginia50@hotmail.com

DOI: 10.1590/1807-3107BOR-2016.vol30.0105

Submitted: Oct 14, 2015

Accepted for publication: May 11, 2016

Last revision: July 8, 2016

\begin{abstract}
The objective of this study was to investigate the association between single nucleotide polymorphisms (SNPs) in the IL10, NOS2A, and ESR2 genes and chronic periodontitis (CP) and aggressive periodontitis $(\mathrm{AgP})$. Three groups of patients underwent periodontal and radiographic evaluations: $\mathrm{CP}(\mathrm{n}=61), \operatorname{AgP}(\mathrm{n}=50)$, and periodontally healthy (control group=61). Genomic DNA was extracted from oral epithelial cells and used for genotyping by real-time polymerase chain reaction using TaqMan ${ }^{\circledR}$ probes. The investigated SNPs were: $-1087 \mathrm{G}>\mathrm{A},-819 \mathrm{C}>\mathrm{T}$ and $-592 \mathrm{C}>\mathrm{A}$ in the IL10; $+2087 \mathrm{G}>\mathrm{A}$ in the NOS2A, and $+1730 \mathrm{G}>\mathrm{A}$ in the ESR2 gene. Differences in genotype and allele frequencies of each polymorphism and some individual characteristics were analyzed using the chi-square test and multivariate logistic regression analysis. Analysis of SNPs and haplotypes in the IL10 and SNP in the ESR2 gene did not present any significant association with AgP or CP. The +2087G allele of the NOS2A gene tended to be significantly associated with periodontal disease. Patients carrying the genotype +2087GG in the NOS2A gene were genetically protected against the development of $\mathrm{CP}(\mathrm{p}=0.05 ; \mathrm{OR}=0.44 ; 95 \% \mathrm{CI}=0.20-0.95)$. This result showed greater significance when patients with $\mathrm{AgP}$ and $\mathrm{CP}$ were combined (total $\mathrm{PD})(\mathrm{p}=0.03$; $\mathrm{OR}=0.46$; 95\%CI $=0.23-0.92$ ). In conclusion, the studied Brazilian population had a significantly higher frequency of the GG genotype for the +2087 SNP in the NOS2A gene in individuals without periodontitis, although statistical significance was not maintained after multiple logistic regression.
\end{abstract}

Keywords: Aggressive Periodontitis; Interleukin-10; Nitric Oxide Synthase; Estrogen Receptor Beta; Single Nucleotide Polymorphism.

\section{Introduction}

Periodontitis is a chronic infectious disease of the supporting tissues of the teeth. Due to bacterial infection, periodontal tissues become inflamed and are slowly destroyed by the action of the inflammatory process, which could lead to tooth loss. ${ }^{1}$ The two main forms of periodontitis are chronic periodontitis $(\mathrm{CP})$ and aggressive periodontitis $(\mathrm{AgP}) .{ }^{2} \mathrm{CP}$ is the most common form of destructive periodontal disease in adults. ${ }^{3}$ $\mathrm{AgP}$ is a rapidly progressing form of periodontal disease that occurs in otherwise clinically healthy individuals ${ }^{4}$ and is characterized by familial aggregation. ${ }^{5}$ 
Periodontitis is considered a complex disease, ${ }^{6}$ since the pathophysiology presents various biological pathways. Complex diseases are associated with variations in multiple genes, each of which has a small overall contribution and relative risk for disease process. ${ }^{1}$ In periodontal disease, the phenotype is determined by both the genetic makeup and the environmental influences on the affected individual. ${ }^{6}$ Most of the genetic research into periodontitis has focused on gene polymorphisms that play a role in immunoregulation or metabolism. ${ }^{6}$

Interleukin-10 is an anti-inflammatory cytokine that plays a role in controlling the inflammatory response., ${ }^{1,6}$ Periodontitis lesions presented a significantly higher expression for IL-10 than that in autologous peripheral blood mononuclear cells.7 Therefore, IL-10 has been considered a candidate susceptibility gene in periodontitis. ${ }^{1}$

Three promoter single nucleotide polymorphisms (SNPs) have been described in the IL10 gene, namely $(-1087) \mathrm{G}>\mathrm{A}$; (-819)C > T; and (-592)C > A, and have been associated with altered IL-10 synthesis in response to inflammatory stimuli. ${ }^{8}$ The SNPs -819 and -592 in the IL10 gene and specific haplotypes were associated with CP in Brazilian patients. ${ }^{9}$ In the IL10 gene, the A allele of the -592 SNP may contribute to a relative increase in the risk for $\mathrm{CP}$, while for -819 gene polymorphism, the $\mathrm{T}$ allele may result in a slight increase in CP susceptibility in Caucasians. ${ }^{10,11}$ The ATA/ATA haplotype was associated with $\mathrm{CP}^{9}$ and $\mathrm{AgP}^{12}$ and with low levels of the IL-10 protein. ${ }^{8}$

Nitric oxide (NO) is a short-lived molecule that plays a key role in many physiological and pathological processes. ${ }^{13}$ Nitric oxide is synthesized from the amino acid L-arginine by NO synthase (NOS) which exists in three distinct isoforms: endothelial (eNOS), neuronal (nNOS), and inducible (iNOS). ${ }^{14}$ iNOS is expressed almost exclusively under inflammatory conditions and is produced by immunocompetent cells, such as macrophages and neutrophils. ${ }^{15}$ Several SNPs within the NOS2A gene could influence its production or activity ${ }^{14,16}$ Increases in iNOS activity have been reported in periodontal disease, suggesting the production and participation of $\mathrm{NO}$ in the disease process. ${ }^{17}$

Estrogens act by binding to and activating two estrogen receptors (ERs), ERa and ER $\beta{ }^{18}$ encoded respectively by two separate genes, ESR1 and ESR $2 .{ }^{19}$ There is evidence in the literature to suggest an association between estrogen and periodontal disease, since ERs were detected in gingival tissues, ${ }_{1}^{19}$ periodontal ligament cells, and jaw bone. ${ }^{20}$ Also, various effects of estrogen on periodontal tissues were found in humans and animals, such as enhancement of cellular proliferation in blood vessels, inhibition of neutrophilic chemotaxis, stimulation of fibroblast proliferation, and change in collagen metabolism. ${ }^{19,20} \mathrm{ER} \beta$ is the most predominant ER in healthy and diseased human gingivae, implying that the effects of estrogen on both health and diseased gingival tissues are mediated by this receptor. ${ }^{19}$ Polymorphisms in both ER genes may modify the effects of endogenous estrogen and have been associated with several pathological conditions, such as cardiovascular disease, ${ }^{21}$ breast cancer, ${ }^{22}$ and $\mathrm{CP} .{ }^{23}$

There are currently few data on the association of polymorphisms in the NOS2A and ESR2 genes with periodontitis, as well as SNPs in the IL10 gene with AgP. Therefore, in the present study, we investigated the association of SNPs in the promoter region of the IL10 gene and its haplotypes, in addition to SNPs in the NOS2A and ESR2 genes, with CP and AgP in Brazilian patients.

\section{Methodology}

This cross-sectional study was conducted at the Periodontology Clinic, in the in the School of Pharmacy, Dentistry, and Nursing, of the Federal University of Ceará, Brazil, between June 2011 and June 2014. The study protocol was approved by the Ethics Committee 098/11. All participants or guardians were informed about the purpose of the study and provided written consent.

\section{Study population}

This study enrolled $42 \mathrm{AgP}, 42 \mathrm{CP}$ and 49 periodontally healthy patients. In addition, 39 family members (parents and/or siblings) of $22 \mathrm{AgP}$ patients were also enrolled (Figure 1). The AgP relatives were included and allocated to the study groups according to their periodontal condition. Six relatives were completely edentulous, with history of tooth loss in adulthood 

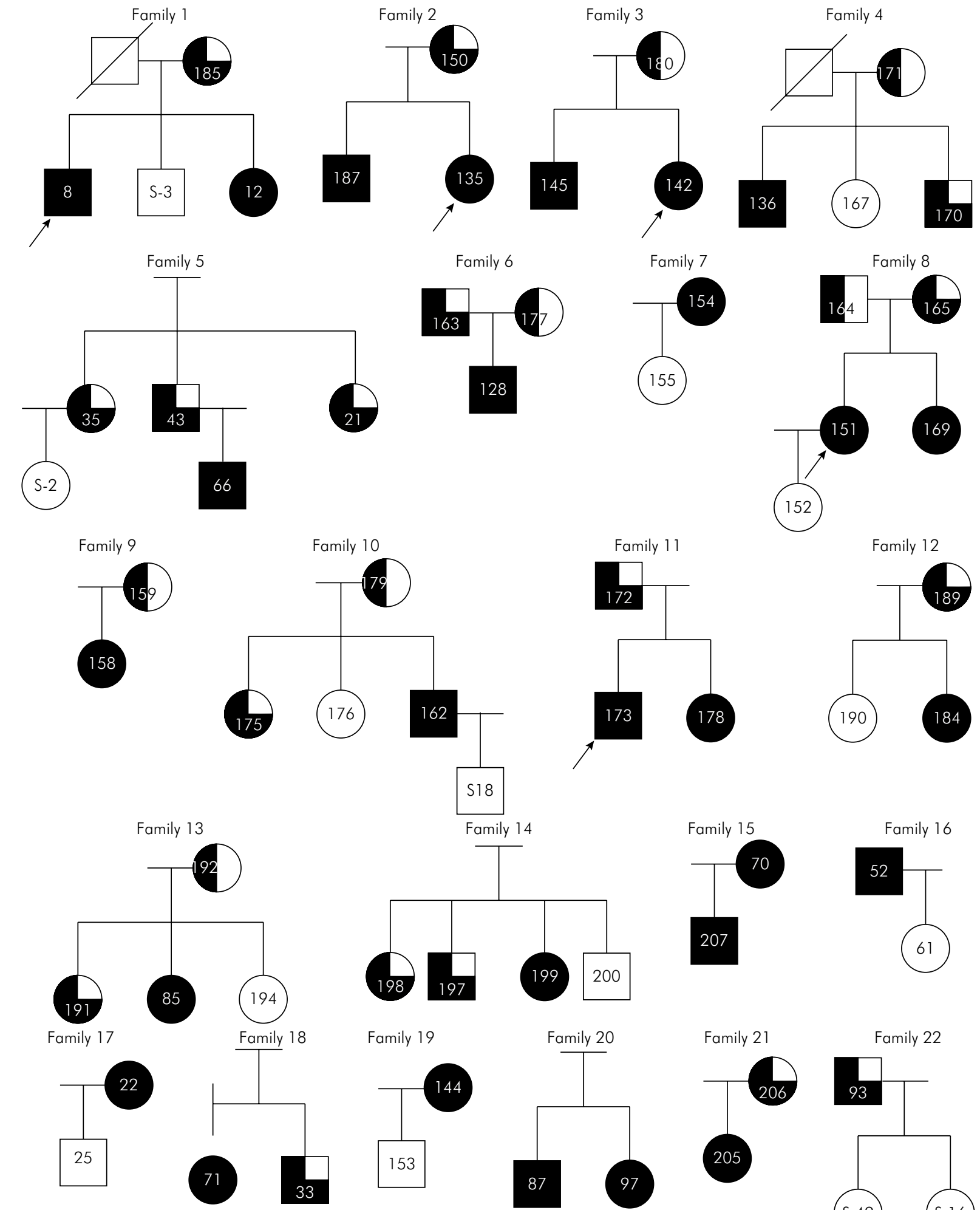

Family 16
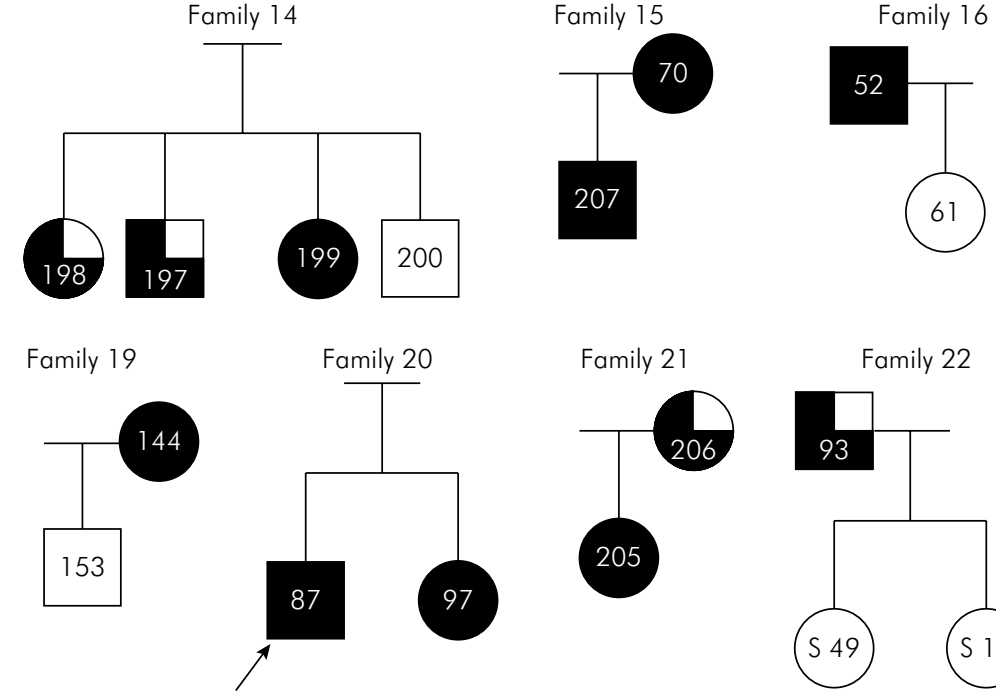

Family 21

Family 22
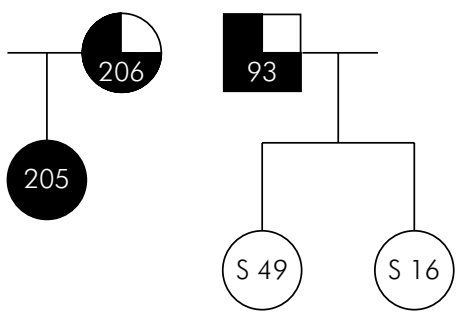

Symbols: $\bigcirc \square$, healthy periodontium; $\square$, affected by chronic periodontitis; $\mathbf{\square}$, affected by aggressive periodontitis; $\boldsymbol{\square}$, totally toothless; $\varnothing \varnothing$, father and/or mother deceased.

Figure 1. Family tree of families affected by AgP. Squares designate males and circles designate females (numbers and letters refer to the patients' codes). The proband is indicated with an arrow in families that have more than one member with AgP. Family members with gingivitis were designated as periodontally healthy. 
due to periodontal disease, and were included in the CP group. Thus, a total of 172 subjects were recruited and placed in three study groups as follows: 50 patients with AgP, 61 patients with $\mathrm{CP}$, and 61 periodontally healthy patients (control group). All of the referent subjects were systemically healthy and non-smokers.

AgP patients were classified according to the clinical criteria proposed by the American Academy of Periodontology (AAP). ${ }^{5} \mathrm{CP}$ patients were also classified according to the same criteria. ${ }^{3,24,25}$ In addition to the $\mathrm{AAP}^{5}$ criteria, patients with $\mathrm{AgP}$ should present age $\geq 12$ and $\leq 40$ years; history of familial aggregation; presence of at least 20 teeth, excluding third molars and including at least three first molars and five incisors; presence of at least three sites on different teeth (other than central incisors or first molars) with probing depth (PD) and clinical attachment loss (CAL) $\geq 5 \mathrm{~mm}$, bleeding on probing (BOP), and radiographic evidence of moderate to severe bone loss.

The control group comprised subjects with at least 24 teeth in the oral cavity, excluding third molars, absence of sites presenting PD and CAL $>3 \mathrm{~mm}$, and presenting gingival index ${ }^{26}<10 \%$; tooth mobility was not found.

The exclusion criteria were as follows: periodontal treatment within the previous 6 months, antibiotic therapy within the previous 3 months, ongoing orthodontic therapy and systemic alterations that could have interfered with periodontal conditions.

\section{Periodontal examination}

All completely erupted permanent teeth, excluding third molars, were submitted to a clinical periodontal examination with the North Carolina manual probe (Trinity ${ }^{\circledR}$, São Paulo, Brazil). The following parameters were evaluated: plaque index (PI), ${ }^{26}$ gingival index (GI), ${ }^{26}$ probing depth (PD), clinical attachment level (CAL), and dichotomous bleeding on probing (BOP) score. PD and CAL were taken at six sites per tooth. A single examiner evaluated all the clinical parameters, and measurement reproducibility was calculated using the intraclass correlation coefficient (ICC) for PD and CAL. The agreement between replicate measurements was high (ICC > 0.80).

\section{DNA collection and genetic polymorphism analysis}

DNA was obtained from buccal epithelial cells $^{27}$ and extracted with ammonium acetate. ${ }^{28}$ DNA concentration was determined with the aid of a spectrophotometer - Nanodrop 2000 (Thermo Scientific, DE, USA), with purity estimated by OD $260 / 280$ ratio and diluted to $10 \mathrm{ng} / \mu \mathrm{l}$.

The analysis of genetic polymorphisms was performed using quantitative real-time polymerase chain reaction (qPCR). The SNPs in the IL10 gene-1082 (G>A) (rs1800896), -819 (C>T) (rs1800871) and -592 (C > A) (rs1800872); in the ESR2 gene +1730 (G > A) (rs4986938); and in the NOS2A gene +2087 (G > A) (rs2297518) were genotyped using predesigned TaqMan SNP Genotyping Assays (Applied Biosystems, Foster City, CA, USA).

DNA amplification was carried out in a $13-\mu 1$ volume containing $1 \mu \mathrm{L}$ of genomic DNA $(10 \mathrm{ng} / \mu \mathrm{l})$, $6.25 \mu \mathrm{L}$ of Master Mix 2x (Applied Biosystems), $0.63 \mu \mathrm{L}$ 20x TaqMan Assay Mix (Applied Biosystems), and 4.63 $\mu \mathrm{L}$ of RNA/DNase free water (Applied Biosystems). The amplifications were made in a StepOne Real-Time PCR System (Applied Biosystems) in 96-well plates. At the end of the reaction, the result was evaluated by observing the groups or clusters of samples that carried each genotype. The distinction between the different genotypes was determined by their particular fluorescence. Each point was determined using the StepOne Real-Time PCR System. The analysis of polymorphisms was performed in the Molecular Genetics Laboratory at the School of Dentistry at Araraquara, UNESP-São Paulo State University.

\section{Data analysis}

Differences in the allele and genotype frequencies of gene polymorphisms were analyzed by the chisquare test and odds ratio using the GraphPad Instat software - version 3.05 (Graph Pad Software Inc. San Diego, CA-USA). A multivariate logistic regression was performed to estimate the relationship between the investigated SNPs and susceptibility to periodontal disease and other covariates (age, gender, CAL, $\mathrm{BOP})$, using the R statistical package (Development Core Team, Vienna, Austria). The distribution of each polymorphism in each group was tested for 
the Hardy-Weinberg equilibrium by means of the ARLEQUIN software, ${ }^{29}$ which was also used to investigate linkage disequilibrium between the loci and the estimated frequency of the possible IL10 haplotypes. The frequency of IL10 haplotypes in different groups was confirmed by manual counting and assessed through the CLUMP software. ${ }^{30}$ All tests were performed at a significance level of $5 \%$.

\section{Results}

The clinical data are summarized in Table 1. The population under investigation was composed mainly of female subjects (65.7\%). All AgP patients showed the generalized form of the disease. The mean age was $28.0 \pm 10.0$ years for the control group, $28.2 \pm 6.5$ years for AgP patients, and $44.9 \pm 11.3$ years for $\mathrm{CP}$ patients, which was statistically different from the other groups $(p<0.05)$. It is important to take into consideration that the present study included direct family members of $22 \mathrm{AgP}$ families. Our findings showed that in most of those families, periodontal disease was present in more than one individual, as either AgP or CP (Figure 1). Unfortunately, the number of families affected by AgP enrolled in this study was insufficient to apply an $\mathrm{AgP}$ family-based association analysis.

Table 1. Demographic and clinical periodontal parameters.

\begin{tabular}{|c|c|c|c|}
\hline \multirow{2}{*}{ Parameters } & Control group & $\mathrm{AgP}$ & $\mathrm{CP}$ \\
\hline & $n=61$ & $\mathrm{n}=50$ & $n=61$ \\
\hline $\begin{array}{l}\text { Age (years; } \\
\text { mean } \pm \text { SD) }\end{array}$ & $28.0 \pm 10.0$ & $28.1 \pm 6.5$ & $44.9 \pm 11.3^{*}$ \\
\hline Male/ Female & $18 / 43$ & $15 / 35$ & $26 / 35$ \\
\hline $\begin{array}{l}\text { Number of teeth } \\
\text { (mean } \pm \text { SD) }\end{array}$ & $26.8 \pm 3.0$ & $25.8 \pm 2.0$ & $22.2 \pm 5.2^{*}$ \\
\hline $\begin{array}{l}\text { PI (\% sites; } \\
\text { mean } \pm \mathrm{SD})\end{array}$ & ne & $33.4 \pm 17.3$ & $37.8 \pm 21.1$ \\
\hline $\begin{array}{l}\text { Gl (\% sites; } \\
\text { mean } \pm \text { SD) }\end{array}$ & ne & $13.7 \pm 19.2$ & $17.2 \pm 19.9$ \\
\hline $\begin{array}{l}\mathrm{PD}(\mathrm{mm} ; \\
\text { mean } \pm \mathrm{SD})\end{array}$ & ne & $3.3 \pm 0.7^{* *}$ & $2.8 \pm 0.7$ \\
\hline $\begin{array}{l}\mathrm{CAL}(\mathrm{mm} ; \\
\text { mean } \pm \mathrm{SD})\end{array}$ & ne & $3.8 \pm 0.9^{* *}$ & $3.5 \pm 1.0$ \\
\hline $\begin{array}{l}\text { BOP (\% sites; } \\
\text { mean } \pm \text { SD) }\end{array}$ & ne & $\begin{array}{l}43.1 \pm \\
17.4^{* *}\end{array}$ & $32.0 \pm 0.2$ \\
\hline
\end{tabular}

AgP: aggressive periodontitis; $\mathrm{CP}$ : chronic periodontitis; PI: plaque index; Gl: gingival index; PD: probing depth; CAL: clinical attachment level; BOP: bleeding on probing; ne: not estimated. ${ }^{*} p<0.05=$ difference between $\mathrm{CP}$ and the other groups; ${ }^{* *} \mathrm{p}<0.05=$ difference between $\mathrm{AgP}$ and $\mathrm{CP}$.
Regarding clinical periodontal aspects, the control group had an average of $26.8( \pm 3.0)$ remaining teeth compared with $25.8( \pm 2.0)$ in the AgP group, and $22.2( \pm 5.2)$ in the CP group. There was a statistically significant difference between the number of teeth in all groups $(\mathrm{p}<0.05)$. The mean number of teeth with $\mathrm{PD}$ and CAL $>3 \mathrm{~mm}$ was, respectively, $19.1( \pm 4.4)$ and $20.4( \pm 3.9)$ for the AgP group, $12.4( \pm 5.3)$ and $15.5( \pm 4.9)$ for the $\mathrm{CP}$ group, and zero for the control group. AgP patients presented signs of severe periodontal destruction and inflammation, as observed from the significantly higher mean of PD, CAL and BOP compared with the $\mathrm{CP}$ groups (Table 1).

Allele and genotype frequencies were not significantly different between control and disease groups regarding any of the three SNPs in the IL10 and ESR2 genes (Table 2). The genotype distributions of each SNP were consistent with the assumption of the Hardy-Weinberg equilibrium for each group. Considering the SNP +2087 in the NOS2A gene, the G allele showed a trend towards a significant association with $\mathrm{CP}(\mathrm{p}=0.07 ; \mathrm{OR}=0.52 ; 95 \% \mathrm{CI}=0.26-1.01)$. Patients carrying the genotype GG were genetically protected against the development of $\mathrm{CP}(\mathrm{p}=0.05 ; \mathrm{OR}=0.44$; $95 \% \mathrm{CI}=0.20-0.95)$. This result was considered significant when $\mathrm{AgP}$ and $\mathrm{CP}$ patients were combined (total PD) $(\mathrm{p}=0.03 ; \mathrm{OR}=0.46 ; 95 \% \mathrm{CI}=0.23-0.92)$ (Table 2). However, the multiple logistic regression analysis demonstrated that the genotypes of any of these genes were not associated with $\mathrm{AgP}$ or $\mathrm{CP}$ after adjusting for common covariates, including age, gender, $\mathrm{CAL}$, and BOP (Table 3). The distribution of haplotypes in the IL10 gene, arranged as genotypes, showed no significant differences between the control and periodontitis groups (Table 4).

Haplotypes as genotypes consisted of $-1082-819$ -592/-1082 -819 -592. Control: healthy patients; AgP: aggressive periodontitis; OR $(95 \% \mathrm{CI})$ : odds ratio values with the respective $95 \%$ confidence intervals; $\mathrm{CP}$ : chronic periodontitis; $\mathrm{p}$-value obtained from the Clump program. Total $\mathrm{PD}=\mathrm{AgP}+\mathrm{CP}$ groups

By utilizing the $\mathrm{G}^{*}$ Power 3 software, the calculations showed that a sample size of 121 individuals demonstrated a power of $77 \%$ for the NOS2A (+2087) genotype analysis between $\mathrm{CP}(\mathrm{n}=60)$ and Control $(\mathrm{n}=61)$, with OR $=0.44$. When Total PD $(\mathrm{AgP}+\mathrm{CP} n=110)$ 
Table 2. Allele and genotype frequencies of the SNPs in the IL10, NOS2A, and ESR2 genes.

\begin{tabular}{|c|c|c|c|c|c|c|c|}
\hline Gene (SNP) & $\begin{array}{l}\text { CONTROL } \\
(\mathrm{n}[\%])\end{array}$ & $\begin{array}{l}\mathrm{AgP} \\
(\mathrm{n}[\%])\end{array}$ & $\mathrm{p}$ & $\begin{array}{c}\mathrm{CP} \\
(\mathrm{n}[\%])\end{array}$ & $p$ & $\begin{array}{c}\text { Total PD (AgP+CP) } \\
(n[\%])\end{array}$ & $\mathrm{p}$ \\
\hline IL 10 (-1082) alleles & $\mathrm{n}=82$ & $n=100$ & & $\mathrm{n}=120$ & & $\mathrm{n}=220$ & \\
\hline A & $60(73.2)$ & $65(65.0)$ & 0.26 & $79(64.8)$ & 0.28 & $144(64.9)$ & 0.21 \\
\hline G & $22(26.8)$ & $35(35.0)$ & 0.26 & $41(33.6)$ & 0.28 & $76(34.2)$ & 0.21 \\
\hline IL 10 (-1082) genotypes & $\mathrm{n}=41$ & $\mathrm{n}=50$ & - & $\mathrm{n}=60$ & - & $n=110$ & - \\
\hline $\mathrm{AA}$ & $23(56.1)$ & $20(40.0)$ & 0.14 & $27(44.3)$ & 0.31 & $47(42.3)$ & 0.19 \\
\hline$A G$ & $14(34.2)$ & $25(50.0)$ & 0.14 & $25(41.0)$ & 0.54 & $50(45.0)$ & 0.45 \\
\hline GG & $4(9.7)$ & $5(10.0)$ & 1.00 & $8(13.1)$ & 0.75 & $13(11.7)$ & 1.00 \\
\hline $\mathrm{H}-\mathrm{W}$ disequilibrium & $p=0.41$ & $p=0.48$ & - & $p=0.56$ & - & $p=0.95$ & - \\
\hline IL 10 (-819) alleles & $n=122$ & $\mathrm{n}=100$ & - & $\mathrm{n}=122$ & - & $\mathrm{n}=222$ & - \\
\hline C & $41(33.6)$ & $37(37.0)$ & 0.67 & $46(37.7)$ & 0.59 & $83(37.4)$ & 0.56 \\
\hline $\mathrm{T}$ & $81(66.4)$ & $63(63.0)$ & 0.67 & $76(62.3)$ & 0.59 & $139(62.6)$ & 0.56 \\
\hline IL 10 (-819) genotypes & $n=61$ & $\mathrm{n}=50$ & - & $\mathrm{n}=61$ & - & $n=111$ & - \\
\hline CC & $28(45.9)$ & $21(42.0)$ & 0.71 & $22(36.1)$ & 0.36 & $43(38.7)$ & 0.25 \\
\hline $\mathrm{CT}$ & $25(41.0)$ & $21(42.0)$ & 1.00 & $32(52.5)$ & 0.28 & $53(47.7)$ & 0.75 \\
\hline $\mathrm{TT}$ & $8(13.1)$ & $8(16.0)$ & 0.79 & 7 (1 1.5) & 1.00 & $15(13.5)$ & 1.00 \\
\hline H-W disequilibrium & $p=0.52$ & $p=0.48$ & - & $p=0.36$ & - & $p=0.83$ & - \\
\hline IL 10 (-592) alleles & $\mathrm{n}=122$ & $n=100$ & - & $\mathrm{n}=122$ & - & $\mathrm{n}=222$ & - \\
\hline C & $80(65.6)$ & $61(61.0)$ & 0.48 & $76(62.3)$ & 0.68 & $137(61.7)$ & 0.48 \\
\hline A & $42(34.4)$ & $39(39.0)$ & 0.48 & $46(37.7)$ & 0.68 & 85 (38.3) & 0.48 \\
\hline IL 10 (-592) genotypes & $n=61$ & $\mathrm{n}=50$ & - & $n=61$ & - & $\mathrm{n}=111$ & - \\
\hline $\mathrm{CC}$ & $27(44.3)$ & $20(40.0)$ & 0.70 & $22(36.1)$ & 0.46 & $42(37.8)$ & 0.25 \\
\hline CA & $26(42.6)$ & $21(42.0)$ & 1.00 & $32(52.5)$ & 0.36 & $53(47.7)$ & 0.87 \\
\hline AA & $8(13.1)$ & $9(18.0)$ & 0.59 & $7(11.5)$ & 1.00 & $16(14.4)$ & 1.00 \\
\hline H-W disequilibrium & $p=0.66$ & $p=0.41$ & - & $p=0.36$ & - & $p=0.91$ & - \\
\hline NOS2A (+2087) alleles & $n=122$ & $\mathrm{n}=100$ & - & $n=122$ & - & $n=222$ & - \\
\hline A & 17 (13.9) & $14(14.1)$ & 1.00 & $29(23.8)$ & 0.07 & $43(19.4)$ & 0.24 \\
\hline G & $105(86.1)$ & $86(86.0)$ & 1.00 & $93(76.2)$ & 0.07 & $179(80.6)$ & 0.24 \\
\hline NOS2A (+2087) genotypes & $n=61$ & $\mathrm{n}=50$ & - & $n=60$ & - & $\mathrm{n}=110$ & - \\
\hline AA & $2(3.3)$ & $0(0.0)$ & 0.50 & $3(4.9)$ & 1.00 & $3(2.7)$ & 1.00 \\
\hline$A G$ & $13(21.3)$ & $14(28.0)$ & 0.51 & $23(37.7)$ & 0.07 & 37 (33.3) & 0.15 \\
\hline \multirow[t]{3}{*}{ GG } & $46(75.4)$ & $36(72.0)$ & 0.83 & $35(57.4)$ & 0.05 & $71(64.0)$ & 0.03 \\
\hline & & & & $O R=0.44$ & & $O R=0,46$ & \\
\hline & - & - & - & $\begin{array}{l}(95 \% \mathrm{CI}= \\
0.20-0.95)\end{array}$ & - & $(95 \% \mathrm{Cl}=0.23-0.92)$ & - \\
\hline H-W disequilibrium & $p=0.38$ & $p=0.24$ & - & $p=0.75$ & - & $p=0.47$ & - \\
\hline ESR2 (+1730) alleles & $n=122$ & $n=100$ & - & $n=122$ & - & $n=222$ & - \\
\hline G & $88(72.1)$ & $75(75.0)$ & 0.65 & $83(68.0)$ & 0.57 & $158(71.2)$ & 0.9 \\
\hline A & 34 (27.9) & $25(25.0)$ & 0.65 & $39(32.0)$ & 0.57 & $64(28.8)$ & 0.9 \\
\hline ESR2 (+1730) genotypes & $\mathrm{n}=61$ & $\mathrm{n}=50$ & - & $\mathrm{n}=61$ & - & $n=111$ & - \\
\hline GG & $30(49.2)$ & $26(52.0)$ & 0.85 & $30(49.2)$ & 1.14 & $56(50.5)$ & 1.00 \\
\hline GA & $28(45.9)$ & $23(46.0)$ & 1.00 & $23(37.7)$ & 0.46 & $46(41.4)$ & 0.33 \\
\hline AA & $3(4.9)$ & $1(2.0)$ & 0.63 & $8(13.1)$ & 0.20 & $9(8.1)$ & 0.75 \\
\hline $\mathrm{H}-\mathrm{W}$ disequilíbrium & $p=0.26$ & $p=0.11$ & - & $p=0.29$ & - & $p=0.91$ & - \\
\hline
\end{tabular}

The control group was compared to each AgP, CP, as well as AgP + CP groups Total PD; $\mathrm{p}$ values were calculated by the chi-square test; Bold: significant result; OR: odds ratio; $\mathrm{Cl}$ : confidence interval. 
Table 3. Multiple logistic regression results for the covariates analyzed.

\begin{tabular}{|c|c|c|c|c|c|}
\hline Patient characteristics & Control $n=61$ & $\mathrm{AgP} n=50$ & $\mathrm{CP} n=61$ & $\mathrm{p}$ & OR $(95 \% \mathrm{Cl})$ \\
\hline Age (mean) & 28.0 & 28.1 & 44.8 & 1.0 & $1.17(0.8-1.72)$ \\
\hline \multicolumn{6}{|l|}{ Gender [n (\%)] } \\
\hline Female & $43(70.5)$ & $35(70)$ & $36(59)$ & & Reference \\
\hline Male & $18(29.5)$ & $15(30)$ & $25(41)$ & 0.88 & $11.19(0.09-15.26)$ \\
\hline BOP\% & NA & 43.12 & 31.97 & 0.78 & $1.01(0.91-1.12)$ \\
\hline CAL (mean) & NA & 3.8 & 3.4 & 1.0 & $0.46(0.05-4.03)$ \\
\hline \multicolumn{6}{|c|}{ IL10 gene polymorphism [n (\%)] } \\
\hline \multicolumn{6}{|c|}{-1082} \\
\hline $\mathrm{AA}$ & $23(56.1)$ & $20(40)$ & $27(44.3)$ & & Reference \\
\hline$A G$ & $14(34.2)$ & $25(50)$ & $25(41)$ & 1.0 & $1.6(0.09-29.53)$ \\
\hline GG & $4(9.7)$ & $5(10)$ & $8(13.1)$ & 0.57 & $2.59(0.02-277.99)$ \\
\hline \multicolumn{6}{|l|}{-819} \\
\hline $\mathrm{CC}$ & $28(45.9)$ & $21(42)$ & $22(36)$ & & Reference \\
\hline TC & $25(41)$ & $21(42)$ & $32(52.5)$ & 0.89 & $1.57(0.1-24.22)$ \\
\hline $\mathrm{TT}$ & $8(13.1)$ & $8(16)$ & 7 (1 1 1.5) & 1.0 & $1.39(0.03-73.96)$ \\
\hline \multicolumn{6}{|l|}{-592} \\
\hline CC & 27 (44.3) & $20(40)$ & $22(36)$ & & Reference \\
\hline$A C$ & $26(42.6)$ & $21(42)$ & $32(52.5)$ & 1.0 & $1.68(0.11-26.38)$ \\
\hline AA & $8(13.1)$ & $9(18)$ & 7 (1 1 1.5) & 1.0 & $1.64(0.05-51.74)$ \\
\hline \multicolumn{6}{|c|}{ NOS2A gene polymorphism [n (\%)] } \\
\hline \multicolumn{6}{|c|}{2087} \\
\hline GG & $46(75.4)$ & $36(72)$ & $35(57.4)$ & & Reference \\
\hline GA & $13(21.3)$ & $14(28)$ & $23(37.7)$ & 1.0 & $1.36(0.1-18.73)$ \\
\hline AA & $2(3.3)$ & 0 & $3(4.9)$ & 1.0 & $268.3(0-8.81)$ \\
\hline \multicolumn{6}{|c|}{ ESR2 gene polymorphism [n (\%)] } \\
\hline \multicolumn{6}{|c|}{1730} \\
\hline GG & $30(49.2)$ & $26(52)$ & $30(49.2)$ & & Reference \\
\hline GA & $28(45.9)$ & $23(46)$ & $23(37.7)$ & 1.0 & $0.94(0.08-10.6)$ \\
\hline AA & $3(4.9)$ & $1(2)$ & $8(13.1)$ & 1.0 & $4.55(0-48.2)$ \\
\hline
\end{tabular}

Control: healthy patients; AgP: aggressive periodontitis; CP: chronic periodontitis; BOP: bleeding on probing; CAL: clinical attachment level; OR $(95 \% \mathrm{Cl})$ : dds ratio values with the respective $95 \%$ confidence intervals.

Table 4. Distribution of IL 10 haplotypes (arranged as genotypes) found in the studied groups.

\begin{tabular}{lcccccccccc}
\hline Genotypes & $\begin{array}{c}\text { Control } \\
(\mathrm{n}[\%])\end{array}$ & $\begin{array}{c}\mathrm{AgP} \\
(\mathrm{n}[\%])\end{array}$ & $\mathrm{p}$ & $\begin{array}{c}\mathrm{OR} \\
(95 \% \mathrm{IC})\end{array}$ & $\begin{array}{c}\mathrm{CP} \\
(\mathrm{n}[\%])\end{array}$ & $\mathrm{p}$ & $\begin{array}{c}\text { OR } \\
(95 \% \mathrm{IC})\end{array}$ & $\begin{array}{c}\text { Total PD } \\
(\mathrm{AgP}+\mathrm{CP}) \\
(\mathrm{n}[\%])\end{array}$ & $\begin{array}{c}\mathrm{p} \\
\mathrm{n}=111\end{array}$ & - \\
\hline GCC/ATA & $13(21.3)$ & $16(32.0)$ & 0.28 & $1.74(0.74-4.08)$ & $15(24.6)$ & 0.83 & $1.20(0.51-2.80)$ & $31(27.9)$ & 0.37 & $1.43(0.68-2.99)$ \\
ATA/ACC & $11(18.0)$ & $5(10.0)$ & 0.28 & $0.50(0.16-1.56)$ & $16(26.2)$ & 0.38 & $1.61(0.68-3.84)$ & $21(18.9)$ & 1.00 & $1.06(0.47-2.38)$ \\
ACC/GCC & $12(9.7)$ & $7(14.0)$ & 0.46 & $0.66(0.24-1.84)$ & $9(14.8)$ & 0.63 & $0.70(0.27-1.82)$ & $16(14.4)$ & 0.39 & $0.69(0.30-1.57)$ \\
ACC/ACC & $11(18.0)$ & $8(16.0)$ & 0.81 & $0.86(0.32-2.35)$ & $4(6.6)$ & 0.09 & $0.32(0.09-1.06)$ & $12(10.8)$ & 0.24 & $0.55(0.23-1.33)$ \\
ATA/ATA & $8(13.1)$ & $7(14.0)$ & 1.00 & $1.08(0.36-3.21)$ & $7(11.5)$ & 1.00 & $0.86(0.29-2.54)$ & $14(12.6)$ & 1.00 & $0.95(0.37-2.43)$ \\
GCC/GCC & $4(6.6)$ & $5(10.0)$ & 0.73 & $1.58(0.40-6.24)$ & $9(14.8)$ & 0.24 & $2.47(0.72-8.49)$ & $14(12.6)$ & 0.30 & $2.06(0.65-6.55)$ \\
ACC/ACA & - & - & - & - & $1(1.6)$ & 1.00 & $3.05(0.12-76.4)$ & $1(0.9)$ & 1.00 & $1.67(0.07-41.6)$ \\
ATA/GTA & - & $1(2.0)$ & 0.45 & $3.73(0.15-93.6)$ & - & - & - & $1(0.9)$ & 1.00 & $1.67(0.07-41.6)$ \\
ATA/GCA & $1(1.6)$ & - & 1.00 & $0.40(0.02-10.0)$ & - & 1.00 & $0.40(0.02-10.0)$ & - & 0.35 & $0.18(0.01-4.51)$ \\
GCC/ACA & $1(1.6)$ & - & 1.00 & $0.40(0.02-10.0)$ & - & 1.00 & $0.33(0.01-8.21)$ & - & 0.35 & $0.18(0.01-4.51)$ \\
ACA/GCA & - & $1(2.0)$ & 0.45 & $3.73(0.15-93.6)$ & - & - & - & $1(0.9)$ & 1.00 & $1.67(0.07-41.6)$ \\
\hline
\end{tabular}


and Control $(n=61)$ were compared, with $O R=0.46$, the sample size of 171 individuals demonstrated a power of $89 \%$. Therefore, the number of subjects enrolled in this study was large enough to detect associations with acceptable level of confidence.

\section{Discussion}

To our knowledge, this is the first study on the +2087 SNP of the NOS2A gene in periodontitis. This study showed a significant association between this gene variant and periodontal disease in a Brazilian population. The NOS2A gene is up-regulated in inflammatory processes, leading to an increased production of $\mathrm{NO} \cdot{ }^{14} \mathrm{~A}$ study showed a higher expression of iNOS in the gingiva of patients with periodontitis than in healthy tissue samples. ${ }^{17}$ High concentrations of NO were associated with severe periodontitis. ${ }^{13}$ The GA genotype of the same SNP in the NOS2A gene investigated here (rs2297518) demonstrated, in a previous study, a tendency towards higher NOS2A activity than the GG genotype. ${ }^{14}$ An increased frequency was found for the A allele in this +2087 SNP in patients with migraines with aura and was consistent with increased iNOS activity in such patients. ${ }^{16}$ This genetic polymorphism leads to an amino acid substitution of serine with leucine in exon 16, which apparently increases iNOS activity and possibly promotes excessive NO formation and inflammation in the presence of the A allele. ${ }^{16}$ In the present study, the GG genotype in the +2087 SNP of the NOS2A gene was significantly associated with periodontitis $(\mathrm{AgP}+\mathrm{CP})$. While the presence of the $\mathrm{G}$ allele seems to indicate a tendency towards protection against the development of $\mathrm{CP}$, patients carrying the GG genotype were, in terms of genetic carriage, significantly better protected against the development of periodontal disease. We suggest that the presence of the $G$ allele in homozygosity could influence the intensity of the host response under bacterial challenge, leading to decreased NO formation and lower inflammation effects in the periodontal tissue. However, considering that $\mathrm{CP}$ is a complex disease, only the carriage of this genotype does not necessarily imply that these patients will be protected against the development of periodontitis.

The three SNPs in the promoter region of the IL10 gene mostly investigated in the literature are $-592(C>A)$,
$-819(\mathrm{C}>\mathrm{T})$, and $-1082(\mathrm{G}>\mathrm{A}){ }^{10,11}$ Two meta-analyses, evaluating case-control studies, concluded that IL10 -819 and -592 gene polymorphisms were associated with CP, especially among Caucasians. ${ }^{10,11}$ The present study showed no evidence of such association, and this result is similar to other cross-sectional studies. ${ }^{31,32}$ Probably, the lack of association between IL10 gene polymorphism and periodontal diseases found in these studies was due to the small number of patients, while in meta-analysis studies, statistics are based on the combination of all the patients included in all studies being evaluated, which results in a larger population sample. In a longitudinal study ${ }^{33}$ with a 5-year follow-up, the IL10 genotype contributed to the progression of periodontal disease. This may reflect the fine balance between IL-10 and disease expression and progression, and the need for prospective longitudinal studies to elucidate the relative contribution of various factors in multifactorial diseases. ${ }^{33}$

This study did not find a significant association between ESR $2+1730(\mathrm{G} / \mathrm{A})$ gene polymorphism and periodontitis. Only few studies have investigated the association of ESR gene polymorphisms and periodontal disease. ${ }^{23,34,35} \mathrm{ERa}$ gene polymorphisms were associated with the number of remaining teeth in postmenopausal Japanese women ${ }^{34}$ and CP in female Han Chinese. ${ }^{23}$

Even though patients' relatives were included in this investigation, it was not possible to perform a family-based association analysis of AgP. However, the inclusion of affected family members was a positive aspect in the present study. Most of the 22 families investigated here had more than one member affected by periodontal disease (AgP or $\mathrm{CP}$, Figure 1 ), corroborating the findings of other studies. ${ }^{36,37}$ Meng et al. ${ }^{38}$ reviewed genetic studies of families affected by AgP. Their findings showed that the familial aggregation of $\mathrm{AgP}$ is often very high among certain families, with the percentage of affected siblings and affected pedigree members reaching $40-50 \%$. This finding suggests that genetic factors may be important in disease susceptibility. Also, those authors suggested that family screening could be used as a preventive diagnostic tool for $\mathrm{AgP} .^{38}$

Clinical diagnosis is the primary method by which $\mathrm{AgP}$ is recognized, but it may be supplemented with 
microbiological and family segregation analysis. However, judging from the amount of periodontal tissue loss that is often present in virtually all of these subjects, periodontal destruction may have initiated earlier, sometimes several years before the diagnosis of the disease. ${ }^{39}$ Future advancement in the understanding of the genetic predisposition to AgP may allow for the inclusion of specific genetic profiles in future case definitions. ${ }^{39}$

Because of the variable characteristics among the groups, mainly age, multiple logistic regression was used to evaluate the influence of these covariates in the association of each SNP in the disease. Considering common periodontal disease covariates in this analysis, the +2087 NOS2A SNP had lost the significance observed with the chi-square test in Table 2. This result could have been different if a larger number of subjects or different ethnicities had been included.

Another positive aspect of the present study is the analysis of SNPs in the IL10 gene as haplotypes. Haplotypes are more powerful in detecting susceptibility alleles than individual polymorphisms, and they may provide more information about the onset of the disease. ${ }^{40}$ Therefore, this suggests that the lack of association between IL10 haplotypes and periodontitis in the investigated population (Table 4) does not seem to be an occasional finding.

\section{References}

1. Laine ML, Crielaard W, Loos BG. Genetic susceptibility to periodontitis. Periodontol 2000. 2012;58(1):37-68. doi:10.1111/j.1600-0757.2011.00415.x

2. Armitage GC. Development of a classification system for periodontal diseases and conditions. Ann Periodontol. 1999;4(1):1-6. doi:10.1902/annals.1999.4.1.1

3. American Academy of Periodontology. Parameters on chronic periodontitis with slight to moderate loss of periodontal support. J Periodontol. 2000;71(5 suppl):853-5.

4. American Academy of Periodontology. Parameters on aggressive periodontitis. J Periodontol. 2000;71(5 suppl):856-8.

5. Tonetti MS, Mombelli A. Early-onset periodontitis. Ann Periodontol.1999;4(1):39-53. doi: 10.1902/annals.1999.4.1.39

6. Yoshie H, Kobayashi T, Tai H, Galicia JC. The role of genetic polymorphisms in periodontitis. Periodontol 2000. 2007;43(1):102-32. doi:10.1111/j.1600-0757.2006.00164.x
Further studies with larger sample populations and with different ethnicities are needed in order to better evaluate the potential association between periodontal disease and polymorphisms in the IL10, ESR2, and NOS2A genes. We can speculate that, in the future, when the role of these genetic factors is finally elucidated, it will be possible to apply this information for the identification of patients at risk, especially for aggressive periodontitis. This will allow for early treatment, thus reducing the functional and esthetic sequelae associated with the disease. ${ }^{20}$

\section{Conclusion}

We conclude that, in the studied Brazilian population, there was a significantly higher frequency of the GG genotype for the +2087 SNP in the NOS2A gene in individuals without periodontitis, although statistical significance was not maintained after multiple logistic regression.

\section{Acknowledgments}

The authors declare no conflicts of interest in this study. This study was supported by grants $\mathrm{CNPq}$ 478161/2007-7, CAPES/PROCAD NF 2313/2008 and 2415/2008 and CAPES/Pro-Equipamentos 60-01/2007. VRSS acknowledges the scholarship from the Coordination for Improvement of Higher Education-CAPES, doctoral program.

7. Yamazaki K, Nakajima T, Kubota Y, Gemmell E, Seymour GJ, Hara K. Cytokine messenger RNA expression in chronic inflammatory periodontal disease. Oral Microbiol Immunol. 1997;12(5):281-7. doi:10.1111/j.1399-302X.1997.tb00392.x

8. Turner DM, Williams DM, Sankaran D, Lazarus M, Sinnott PJ, Hutchinson IV. An investigation of polymorphism in the interleukin-10 gene promoter. Eur J Immunogenet. 1997;24(1):1-8. doi:10.1111/j.1365-2370.1997.tb00001.x

9. Scarel-Caminaga, RM, Trevilatto PC, Souza AP, Brito RB, Camargo LE, Line SR. Interleukin 10 gene promoter polymorphisms are associated with chronic periodontitis. J Clin Periodontol. 2004;31(6):443-8. doi:10.1111/j.1600-051X.2004.00500.x

10. Zhong Q, Ding C, Wang M, Sun Y, Xu Y. Interleukin-10 gene polymorphisms and chronic/aggressive periodontitis susceptibility: a meta-analysis based on 14 case-control studies. Cytokine. 2012;60(1):47-54. doi:10.1016/j.cyto.2012.05.014 
11. Albuquerque CM, Cortinhas AJ, Morinha FJ, Leitão JC, Viegas CA, Bastos EM . Association of the IL-10 polymorphisms and periodontitis: a meta-analysis. Mol Biol Rep. 2012;39(10):9319-29. doi:10.1007/s11033-012-1738-1

12. Reichert S, Machulla HK, Klapproth J, Zimmermann $\mathrm{U}$, Reichert $\mathrm{Y}$, Gläser $\mathrm{CH}$ et al. The interleukin-10 promoter haplotype ATA is a putative risk factor for aggressive periodontitis. J Periodontal Res. 2008;43(1):40-7. doi:10.1111/j.1600-0765.2007.00992.x

13. Han DH, Kim MS, Shin HS, Park KP, Kim HD. Association between periodontitis and salivary nitric oxide metabolites among community elderly Koreans. J Periodontol. 2013;84(6):776-84. doi:10.1902/jop.2012.120237

14. Wang Z, Feng K, Yue M, Lu X, Zheng Q, Zhang $\mathrm{H}$, et al. A non-synonymous SNP in the NOS2 associated with septic shock in patients with sepsis in Chinese populations. Hum Genet. 2013;132(3):337-46. doi:10.1007/s00439-012-1253-4

15. Kendall HK, Marshall RI, Bartold PM. Nitric oxide and tissue destruction. Oral Dis. 2001;7(1):2-10. doi:10.1034/j.1601-0825.2001.70102.x

16. Mansur TOS, Gonçalves FM, Martins-Oliveira A, Speciali JG, Dach F, Lacchini R et al. Inducible nitric oxide synthase haplotype associated with migraine and aura. Mol Cell Biochem. 2012;364(1-2):303-8. doi:10.1007/s11010-012-1231-0

17. Shaker O, Ghallab NA, Hamdy E, Sayed S. Inducible nitric oxide synthase (iNOS) in gingival tissues of chronic periodontitis with and without diabetes: immunohistochemistry and RT-PCR study. Arch Oral Biol. 2013;58(10):1397-406. doi:10.1016/j.archoralbio.2013.05.003

18. Zhao C, Dahlman-Wright K, Gustafsson J-Å. Estrogen signaling via estrogen receptor $\{$ beta\}. J Biol Chem. 2010;285(51):39575-9. doi:10.1074/jbc.R110.180109

19. Nebel D, Bratthall G, Ekblad E, Norderyd O, Nilsson BO. Estrogen regulates DNA synthesis in human gingival epithelial cells displaying strong estrogen receptor $\beta$ immunoreactivity. J Periodontal Res. 2011;46(5):622-8. doi:10.1111/j.1600-0765.2011.01382.x

20. Shapiro LF, Freeman K. The relationship between estrogen, estrogen receptors and periodontal disease in adult women: a review of the literature. N Y State Dent J. 2014;80(3):30-4.

21. Marini H, Currò M, Adamo EB, Polito F, Ferlazzo N, Bitto A, et al. The ESR2 AluI 1730G>A (rs4986938) gene polymorphism is associated with fibrinogen plasma levels in postmenopausal women. Gene. 2012;508(2):206-10 . doi:10.1016/j.gene.2012.08.004

22. Yu KD, Rao NY, Chen AX, Fan L, Yang C, Shao ZM. A systematic review of the relationship between polymorphic sites in the estrogen receptor-beta (ESR2) gene and breast cancer risk. Breast Cancer Res Treat. 2011;126(1):37-45. doi:10.1007/s10549-010-0891-2
23. Zhang L, Meng H, Zhao H, Li Q, Xu L, Chen Z, et al. Estrogen receptor-alpha gene polymorphisms in patients with periodontitis. J Periodontal Res. 2004;39(5):362-6. doi:10.1111/j.1600-0765.2004.00736.x

24. Flemmig TF. Periodontitis. Ann Periodontol. 1999;4(1):32-8. doi:10.1902/annals.1999.4.1.32

25. American Academy of Periodontology. Parameter on Chronic periodontitis with advanced loss of periodontal support. J Periodontol. 2000;71(5 Suppl):856-8.

26. Ainamo J, Bay I. Problems and proposals for recording gingivitis and plaque. Int Dent J. 1975;25(4):229-35.

27. Pigossi SC, Alvim-Pereira F, Montes CC, Finoti LS, Secolin $\mathrm{R}$, Trevilatto PC, et al. Genetic association study between Interleukin 10 gene and dental implant loss. Arch Oral Biol. 2012;57(9):1256-63. doi:10.1016/j.archoralbio.2012.02.020

28. Aidar M, Line SRP. A simple and cost-effective protocol for DNA isolation from buccal epithelial cells. Braz Dent J. 2007;18(2):148-52. doi:10.1590/S0103-64402007000200012

29. Excoffier L, Laval G, Schneider S. Arlequin (version 3.0): An integrated software package for population genetics data analysis. Evol Bioinform Online. 2007;1(1): 47-50.

30. Sham PC, Curtis D. Monte Carlo tests for associations between disease and alleles at highly polymorphic loci. Ann Hum Genet. 1995;59(Pt 1):97-105. doi:10.1111/j.1469-1809.1995.tb01608.x

31. Yamazaki K, Tabeta K, Nakajima T, Ohsawa Y, Ueki K, Itoh $\mathrm{H}$, et al. Interleukin-10 gene promoter polymorphism in Japanese patients with adult and early-onset periodontitis. J Clin Periodontol. 2001;28(9):828-32. doi:10.1034/j.1600-051x.2001.028009828.x

32. Brett PM, Zygogianni P, Griffiths GS, Tomaz M, Parkar $\mathrm{M}$, et al. Functional gene polymorphisms in aggressive and chronic periodontitis. J Dent Res. 2005;84(12): 1149-53. doi:10.1177/154405910508401211

33. Cullinan MP, Westerman B, Hamlet SM, Palmer JE, Faddy MJ, Seymour GJ,et al. Progression of periodontal disease and interleukin-10 gene polymorphism. J Periodontal Res. 2008;43(3):328-33. doi:10.1111/j.1600-0765.2007.01034.x

34. Taguchi A, Kobayashi J, Suei Y, Ohtsuka M, Nakamoto $\mathrm{T}$, Tanimoto $\mathrm{K}$ et al. Association of estrogen and vitamin $\mathrm{D}$ receptor gene polymorphisms with tooth loss and oral bone loss in Japanese postmenopausal women. Menopause. 2003;10(3):250-7. doi:10.1097/00042192-200310030-00013

35. Zhang X, Dai J, Long Y, Wu H, Li XJ, Ding Y. Correlation of estrogen receptor alpha gene polymorphisms and bone mineral density in Chinese women with chronic periodontitis. Chin Med J. 2010;123(22):3262-7. doi:10.3760/cma.j.issn.0366-6999.2010.22.017

36. Marazita ML, Burmeister JA, Gunsolley JC, Koertge TE, Lake K, Schenkein HA. Evidence for autosomal dominant inheritance and race-specific heterogeneity in early-onset periodontitis. J Periodontol. 1994;65(6):623-30. doi:10.1902/jop.1994.65.6.623 
37. Hodge PJ, Teague PW, Wright AF, Kinane DF. Clinical and genetic analysis of a large North European Caucasian family affected by early-onset periodontitis. J Dent Res. 2000;79(3):857-63. doi:10.1177/00220345000790031201

38. Meng H, Ren X, Tian Y, Feng X, Xu L, Zhang L, et al. Genetic study of families affected with aggressive periodontitis. Periodontol 2000. 2011;56(1):87-101. doi:10.1111/j.1600-0757.2010.00367.x
39. Albandar JM. Aggressive periodontitis : case definition and diagnostic criteria. Periodontol 2000. 2014;65(1):13-26. doi:10.1111/prd.12014

40. Scarel-Caminaga RM, Kim YJ, Viana AC, Curtis KM, Corbi SC, Sogumo PM et al. Haplotypes in the interleukin 8 gene and their association with chronic periodontitis susceptibility. Biochem Genet. 2011;49(5-6):292-302. doi:10.1007/s10528-010-9407-3 